\title{
İzmir'in Fikir, Sanat ve Edebiyat Tarihine Önemli Bir Katkı
}

\author{
Prof. Dr. Zeki ARIKAN*
}

İzmir, XVI. yüzyılın ikinci yarısından başlamak üzere bütün tarih boyunca depremler, felaketler, yangınlar, salgın hastalıklara rağmen Doğu Akdeniz'in Batı'ya açılan en önemli limanlarından biri olmuştur. İzmir, İran'dan gelen ipeğin, Ankara'dan gelen tiftiğin, Yemen'den gelen kahvenin transit ticareti yanında, doğrudan doğruya art bölgeden elde edilen ürünlerin de bir kavşak, bir ihraç noktasıydı. Bu ticarî etkinlik, kentin fiziksel yapısını da etkilemiş, özellikle XVII. yüzyıldaki büyük imar hareketleri İzmir'e giderek Avrupaî bir görünüm vermiş̧ir. Daha söz konusu yüzyılda Avrupalı tüccar, diplomat, konsolos, gezgin vb. İzmir'in sosyal yaşamında büyük bir rol oynamaya başlamıştı. Kumpanyalarla, eğlencelerle Doğu-Batı'nın kültürel değerlerinin kaynaştığı bir yer olma özelliğini gösteren İzmir, XIX. yüzyılda limanı, art bölgelere bağlayan demiryolları ve rıhtım inşaatının tamamlanmasıyla çok daha önemli bir liman kenti konumuna yükseldi.

İzmir, Tanzimat dönemine, diğer Anadolu kentlerine göre daha uygun koşullarda girdi. Tanzimatla birlikte bu havzada yeni bir yaşam başladı. $\mathrm{Bu}$ yeni yaşamın özelliği, İzmir havzasının giderek Avrupa sermayedarlarının etkinliklerine açık olmasıydı. Türkiye'nin en önemli ekonomi merkezlerinde işlemeğe başlanan Avrupalılar, İstanbul'dan sonra kendilerine en uygun Anadolu kenti olmak üzere İzmir'i seçtiler ve orada yerleşerek sermaye dünyasını, ticaret komisyonculuğu göreviyle İzmir havzasının dünya piyasasıyla olan ilişkilerini yönetmeye başladılar ${ }^{1}$. Demiryolları bir taraftan üretimin artmasına olanak verirken, diğer yandan da bu bölgede Avrupa'nın ithal ürünlerinin çoğalmasına fırsat verdi. İzmir'in Frenk Mahallesi (Alsancak), Avrupalıların bu bölgeyle ilişkilerini sağlayan, aynı zamanda Doğu'ya yerleşmiş olan Levantenleri barındıran, Avrupa kültürünün ağır bastığı bir mekan olarak görünmektedir. Doğu'ya ekonomileriyle, kültürleriyle, yaşam biçimleriyle yerleşmiş bulunan Avrupalılar, İzmir'de

\footnotetext{
• Ege Üniversitesi, Edebiyat Fakültesi Öğretim Üyesi.

${ }^{1}$ Muhittin, “Türkiye'nin En Mühim Servetlere Sahip İktisat Havzası: İzmir”, Meslek, 15 Kânunevvel 1341 (1925), s.9.
} 
kültürel bir varlık göstermekten de geri kalmamışlardır ${ }^{2}$. Nitekim Türkiye'de ilk Fransızca gazeteler İzmir'de yayınlanmıştır. Bunu gayrimüslim uyrukların çıkardıkları gazeteler izlemiştir. Yabancıların aracı olarak çoğu kez gayrimüslim uyrukları kullanmaları onların da ekonomik yönden önemli bir varlık göstermelerine ortam hazırlamıştır. Yalnız şunu da kabul etmek gerekir ki İzmir ve art bölgesindeki ekonomik gelişmelerden Türk unsurlarının da, yavaş yavaş da olsa, etkilendiklerine şüphe yoktur. Muhittin (Birgen)'in anlatımına göre, "Avrupa ile münasebetlerimizin çoğalması ve nihayet memlekette cereyan eden iktisat hareketlerinin kesafet kesbetmesi gibi sebeplerden Türkler de istifadesiz kalmış olmayacaklarına göre onların arasında da servet terakümleri (birikimleri) başlamıs, bir dereceye kadar refah ve umran eserleri görülmemiş değildir; ancak gayri Türklerin kazançları ile Türklerin kazançları arasında büyük bir fark vücuda geldiği muhakkaktır"3. İzmir'de kağıt ve un fabrikalarıyla birlikte birtakım sınai tesislerin kurulmasını da önemli bir gelişme olarak değerlendirebiliriz ${ }^{4}$. Ancak burada yaşayan Türklerin kültürel yaşama katkıları epeyce geç başlamıştır diyebiliriz. İlk Türkçe kitapların yabancı matbaalarda basıldığına şüphe yoktur. Un fabrikasına ait bir nizamnamenin İzmir'de taşbasma olarak basılmış ilk Türkçe kitap olduğunu sanıyoruz (1948). 1869 yılında vilayet gazetesinin çıkması ve vilayet matbaasının kurulması, İzmir'de kültürel yaşamın önemli bir aşaması olarak görülmektedir. Çünkü bu matbaa, özel Türk matbaaları kuruluncaya kadar ilk çıkan özel Türk gazetesinin, Türkçe basılan kitapların önemli bir çıkış kapısı ödevini görmüştür. İntibah ve Devir gibi ilk Türkçe özel gazeteler de ne yazık ki yeterli okuyucuyu bulamadıkları için kısa sürede kapanmak zorunda kalmışlardır. 1884'te üç gencin (Halit Ziya, Tevfik Nevzat, Bıçakçızade Hakkı) çıkardığı Nevruz başlıklı bir edebiyat dergisi, Ziya Somar'ın deyimiyle, İzmir'de ilk Türk fikrinin uyanışı... büyük ve derin bir silkinişi ve uyanmak ihtiyacının bir dışavurumu idi $^{5}$. Bunu Hizmet, Ahenk, İzmir vb. gazeteler izledi. İkinci Meşrutiyet dönemi İzmir için de büyük bir uyanış dönemi oldu. Kooperatifleşme çabaları, özel okullar, gazeteler, dergiler, konferanslar, Türk Ocağı'nın açılması, Milli Kütüphane'nin kurulması vb. İzmir'in ekonomik ve kültürel yaşamına yeni açılımlar sağladı. Fikir yaşamı büyük bir canlılık gösterdi. Ama İzmir, imparatorluk döneminde ne yazık ki bir yüksek öğretim kurumuna kavuşamadı. Bu yüzdendir ki İzmir'in Türkiye'nin geleceğinde büyük bir rol üstlenecek olan gençleri yüksek öğrenim için sürekli olarak İstanbul'a koştular. Selanik'in kaybı üzerine oradaki Hukuk Mektebi'nin İzmir'e taşınması gündeme geldiyse de bu hiçbir zaman gerçekleşmedi. İşgal, İzmir'deki kültürel gelişmelere ağır bir darbe vurdu. Kurtuluşla

\footnotetext{
${ }^{2}$ Rauf Beyru, 19. Yüzyılda İzmir'de Yaşam, Literatur Yayıncılık, İstanbul 2000.

${ }^{3}$ Muhittin, "Türkiye'nin....", göst. yer.

${ }^{4}$ Abdullah Martal, Değişim Sürecinde Izmir'de Sanayileşme, 19. Yüzyll, Dokuz Eylül Yayınları, İzmir 1999.

${ }^{5}$ Ziya Somar, Yakın Çağların Fikir ve Edebiyat Tarihinde Izmir, İzmir 1944. (Bu eser Büyükşehir Belediyesi tarafından yeniden basıldı, İzmir 2001):
} 
birlikte başlayan yeni bir toparlanma, yeni bir uyanış, İzmir'in yeni bir kültürel gelişme sürecine girmesine ortam hazırladı.

İzmir bu tarihsel süreç içinde birçok yazar, şair, sanatçı, gazeteci, tek bir sözcükle birçok aydın yetiştirdi. Ama İzmir hiçbir zaman bir İstanbul olamadı. Türk edebiyatının, Türk düşün yaşamının en büyük adlarından biri olan Halit Ziya, çok erkenden bu farkı duyumsamış ve en önemli eserlerini vereceği İstanbul'un yolunu tutmuştur.

İzmir'in kültürel yaşamında önemli bir yer tutan insanların yaşamı ve yapıtları üzerine şimdiye kadar kimi çalışmalar yapılmıştır. Meşrutiyet'in ilanından önce Alaşehir taburunda görev yapan Bursalı Tahir, bu yörede yaptığı araştırmaların sonuçlarını Aydın Vilayetine Mensup Meşayıh, Ulema, Şuara, Müverrihin ve Etibbanın Teracim-i Ahvali (İzmir, 1324/1908) başlığı altında yayınlandı. Bu eser, yazarın daha sonra yayınlayacağ ${ }_{1}$ Osmanlt Müellifleri adını taşıyan büyük çalışması için de bir model olması açısından önemlidir. İbnülemin Mahmut Kemal, Son Asır Türk Şairleri (İstanbul, 1930-1942)'nde İzmirli şairlere de önemli bir yer vermiştir. Hüseyin Avni Ozan'ı İzmir Şairleri Antolojisi (İzmir, 1934) ise İzmir ve çevresinde daha doğrusu eski Aydın vilayetinde yetişmiş 146 şairi incelemiştir. Bugün ise bütün bu çalışmaları önemli ölçüde aşan kapsamlı bir araştırma elimizin altında bulunmaktadır. Bu, Prof. Dr. Ömer Faruk Huyugüzel'in İzmir üzerine yıllardan beri yapmakta olduğu araştırmaların bir devamı, deyim yerinde ise bir bilançosudur ${ }^{6}$. Yazar, bu konuda yukarıda değindiğim çalışmalara işaret ederek şöyle demektedir: "Bizim araştırmamız işte bu eserlerin bir nevi devamı veya benzeridir. Daha doğrusu bunlardaki bilgilerden yola çıkarak, birkaç yazar dışında bunlardaki yazarlara ait bilgileri eleştirerek düzeltip genişletmekte ve kapsamı doğrultusunda bu eserlerde yer almayan 20. yüzyılın ilk yarısında ün kazanmış birçok yeni fikir ve sanat adaminin biyografisini de genis şekilde vermektedir. Böylece İzmir Halkevi tarafindan bundan altmış yedi yıl önce başlatılan "Yazı ve Fikir Adamları" projesi bugün imkânlar ölçüsünde tamamlanmış olmaktadır.” (s. X). Sonuçta, Kültür Bakanı sayın İstemihan Talay'ın vurguladığı gibi: "İzmir Fikir ve Sanat Adamları (1850-1950)" adll bu araştırmayla İzmir Halkevi'nin tasarladı̆̆ı proje, en azından yüz yıllık bir dönem için gerçekleşmiş olmaktadır. Kitapta İzmir'de yaşamış veya burada bir süre bulunmuş 262 fikir ve sanat adaminın biyografi ve eserleri ortaya konulmuştur. Böylece bir bakıma bir kentin söz konusu dönemdeki fikir ve sanat tarihi de temel çizgileriyle gün ışığına çıkarılmaktadır." (s. V)

$\mathrm{Bu}$ araştırma kamuoyunda önemli bir ilgi gördü. Doğan Hızlan, kitabın önemini belirten bir yazı kaleme aldı ve "ayrıca Türkçe eser vermiş Rum, Ermeni ve Yahudi sanat, fikir adamlarına da kitapta yer verilmiş" olmasını

${ }^{6}$ Ö. Faruk Huyugüzel, İzmir Fikir ve Sanat Adamlarl (1850-1950), Kültür Bakanlığı Yayınları/2509, Yayımlar Dairesi başkanlığı Kültür Eserleri Dizisi/280, Ankara, 2001, $\mathrm{XIII}+640 \mathrm{~s}$. 
takdirle karşıladı ${ }^{7}$. Bu doğrudur ve elbette bir ülkenin ekonomik, sosyal, kültürel yönden yükselmesi ve ileriye gitmesi, o ülkede yaşayan bütün insanların, dil, din, soy ayrımı olmaksızın bütün insanların, ortak çabalarına bağlıdır. Öte yandan Yaşar Aksoy da İzmir Kitap Fuarı'nda (2001) düzenlenen bir panelde, söz konusu bu araştırmanın önemini dile getiren bir konuşma yapmiştır.

Ali Tekinci ise araştırmanın eksikleri üzerinde durmakta, unutulmuş bir iki yazarı ön plana çıkarmaya çalışmakta ve Sicill-i Ahval dosyalarından, mezar taşlarından ve özellikle İzmirli ailelerden niçin yararlanılmadığını gündeme getirmektedir ${ }^{8}$. Öncelikle şunu belirtelim. Bu kadar kapsamlı bir çalışmada bir iki yazarın unutulmasını doğal karşılamak gerekir. Bilindiği gibi Sicill-i Ahval dosyaları, imparatorluk döneminde devlet memurluğu görevinde bulunanların olumluk kayıtlarının tutulduğu defterlerdir. Bu defterler Başbakanlık Osmanlı Arşivi'nde bulunmakta, şimdi yapılan dizinleri sayesinde bunlardan yararlanmak daha kolaylaşmış bulunmaktadır. Ancak her memurun sicil kaydını bulmak kolay değildir. Kaldı ki birkaç yüz kişinin, burada sicilini arayıp çıkarmanın neye mal olacağını kestirmek de pek kolay değildir. İzmirli ailelerden yararlanma konusuna gelince: Bugün şüphesiz İzmir'in saygın ailelerinin ellerinde yakın tarihimizde önemli rol oynamış kişilerle ilgili pek çok bilgi ve belgenin bulunduğuna şüphe yoktur. Fakat bu ailelerle iletişim kurmak ve belgelere ulaşmak o kadar kolay değildir. Kişisel olmakla birlikte, benim gibi herkesin başına gelebilecek bir iki örnek vermek istiyorum: Köylü gazetesi ve onun sahibi Mehmet Refet üzerine yapmakta olduğum bir araştırma sırasında, onun ailesinden kimilerine telefonla ulaştım. Ancak buluşma isteğim her defasında geri çevrildi. En sonunda telefondaki sinirli ses, filan kişinin bu konuda çok şey bildiğini ve ona başvurmamı salık verdi. İkinci bir örnek: Atatürk'ün Adalet Bakanı Mahmut Esat Bozkurt'un yazdığı Atatürk İhtilali'nin karalama halinde bulunan ikinci cildini, bin bir güçlükle yeni yazıya aktardım ve eserde bulunması gereken, fakat sonradan konulacağı düşüncesiyle verilmeyen belgeleri bulup gerekli boşlukları tamamladım. Bazı yerlere de gerekli açıklamalar yapmak zorunda kaldım. Sonunda Mahmut Esat'ın aile bireyleri bu "müdahalelerim"den bir hayli rahatsız oldu ve kitabın basımı durduruldu. Öte yandan İzmir'in mezarlıklarını yakından bilenler, bunların yerlerinin çoktan beri meskun mahal haline geldiğini görenler, bu alanda yapılacak araştırmalardan pek olumlu sonuç alınamayacağını da takdir ederler.

Demek istediğim şu: Bizdeki "erbab-1 ilim ve kalem" eleştiriye değil, fakat yıkmaya pek meraklıdır. İlk çıkış noktaları "Falan filan eser görülmemiş"le başlar ve yapılan işi, verilen emeği bir anda sıfıra indirmeye

${ }^{7}$ Doğan Hızlan, “İzmir'i İzmir Yapanlar”, Hürriyet, 14 Nisan 2001.

${ }^{8}$ Ali Tekinci, "Izmir. Fikir ve Sanat Adamları (1850-1950) Hakkında I", Türk Yurdu, XXI/162-163 (2001), 402-403; II, XXI/164 (2001), 55-56; III, XXI/166, 51-53; IV, XXI/167, 36-39. 
kalkarlar. Kendilerine incelemek üzere gönderilen tezlerin kenarlarına: "Bu tezi yönetenlerin hiçbir şeyden haberi yokmuş!" anlamına gelen "şerhler" düşmekten psikolojik bir rahatlama duyarlar. Ama kendilerinin "Evraka, Evraka!" diye bulup kurdukları karton bina, bir kalem darbesiyle yerle bir olur. Fakat yine de saldırganlıklarını sürdürmekten geri kalmazlar... Demek istediğim şu; Çok geniş kapsamlı böyle bir çalışma için Sicill-i Ahval'in, mezar taşlarının eserin bibliyografyasında görülmemesi araştırmanın değerini düşürmez.

Prof. Huyugüzel, Ege Üniversitesi Edebiyat Fakültesi'nde konuyla ilgili büyük bir arşiv kurmuştur. Bu arşivin temel malzemesini öğrencilerin lisans, yüksek lisans ve doktora düzeyinde yaptıkları tezler oluşturmaktadır. Bu tezler bugün ancak İzmir Milli Kütüphanesi'nde bulunabilen İzmir çıkışlı gazete, dergi ${ }^{9}$ ve diğer kaynaklara dayanmaktadır. Bu bakımdan Huyugüzel'in eseri, İzmirli fikir ve sanat adamları hakkında ansiklopedik bilgi veren bir derleme olmaktan çıkmış ve pek çoğu özgün bir araştırma niteliği kazanmıştır. Yalnız bir iki örnek vermek için Evangelinos Misailidis, Nasıf Ma'luf, Mahmut Esat Efendi (Seydişehri), Grigorios karydis, Gad Franko vb. ile ilgili bölümleri işaret etmekle yetiniyorum. Bu ve daha pek çok yazar hakkındaki bölümler, ilk kez yapılan derli toplu bir araştırma niteliği taşımaktadır.

Eserin eksikleri yok mu? Elbette var. Mahmut Esat Bozkurt, Hikmet Turhan Dağlıoğlu, Kemal Turan, Ethem Nejat, Muhittin Birgen, Karolidi Efendi vb. de bu eserde olmalıyd. Hasan Tahsin, Ziya Somar üzerine yapılan en son araştırmalar ihmal edilmiștir. Bu yüzdendir ki "ilk kurşun" konusunda var olan bilgilerin herhangi bir kaynağa dayanmadığı yargısına varılmıştır. Asıl üzerinde durmak istediğimiz dizinin son derece yetersiz oluşudur. Çünkü dizin yalnızca kitapta yer alan fikir ve sanat adamlarının alfabetik listesini ve bunların yine alanlarına göre düzenlenmiş ikinci bir alfabetik listesini kapsamaktadır. Oysa kitapta, çalışma konusu olarak verilen yazarların dışında pek çok kimsenin adı geçmektedir. Hele hele kitap adları?.. Burada çalışmanın temelini oluş̧uran yüzlerce kitap adı geçmektedir. Bunlarla ilgili ayrıntılı bir dizin yapılmamış olmasını önemli bir boşluk olarak kabul ediyoruz. Bu eksikliklerin kitabın bundan sonraki baskılarında dikkate alınması gerekir. Sonuç olarak Prof. Huyugüzel'in çalışmasını, İzmir'in yazılı kültürüne son yıllarda yapılmış önemli katkılardan biri olarak kabul ediyoruz.

${ }^{9}$ Ö. Faruk Huyugüzel, 1928 'e Kadar Izmir'de Çıkmış Türkçe Kitap ve Süreli Yayınlar Kataloğu, İzmir, 1996. Krş. Erkan Serçe, Izmir'de Kitapçılık, 1839-1928, İzmir, 1996. 